Supporting Information

\title{
Sacrificial Substrate-Free Whole-Cell Biocatalysis for The Synthesis of 2,5-Furandicarboxylic Acid by Engineered Escherichia coli
}

\author{
Xin Wang, ${ }^{\dagger}$ Xue-Ying Zhang, ${ }^{\dagger}$ Min-Hua Zong, ${ }^{\dagger}$ Ning $\mathrm{Li}^{*}, \dagger$ \\ ${ }^{\dagger}$ School of Food Science and Engineering, South China University of Technology, 381 \\ Wushan Road, Guangzhou 510640, China \\ * Corresponding author. \\ Dr. N. Li, Email: lining@scut.edu.cn
}

The number of pages: 13

The number of figures: 8

The number of tables: 3 


\section{Experimental}

\section{Chemicals}

HMF (99\%) was purchased from Aladdin (Shanghai, China). HMFCA (98\%) was purchased from Adamas Reagent Ltd (Shanghai, China). FFCA (98\%) and FDCA (97\%) were from J\&K Scientific Ltd (Guangzhou, China). BHMF (98\%) was obtained from Macklin Biochemical Co., Ltd (Shanghai, China). DFF (>98\%) was purchased from TCI (Japan). Other chemicals are of analytical grade and commercially available.

\section{Strains, plasmids, primers}

The strains, plasmids and primers used in this study were summarized in Table S1. E. coli $\mathrm{DH} 5 \alpha$ was used for construction and propagation of plasmids. E. coli BL21(DE3) was used as the host strain to express $\mathrm{HmfH}$ and ALDHs. Luria-Bertani (LB) medium ( $5 \mathrm{~g} / \mathrm{L}$ yeast extract, $10 \mathrm{~g} / \mathrm{L}$ tryptone, and $10 \mathrm{~g} / \mathrm{L} \mathrm{NaCl}$ ) supplemented with appropriate antibiotics (17 mg/L of chloramphenicol and/or $25 \mathrm{mg} / \mathrm{L}$ of kanamycin) as indicated and Terrific-Broth (TB) medium (24 g/L yeast extract, $12 \mathrm{~g} / \mathrm{L}$ tryptone, $4 \mathrm{ml} / \mathrm{L}$ glycerol, $72 \mathrm{mM} \mathrm{K}_{2} \mathrm{HPO}_{4}$, and $17 \mathrm{mM} \mathrm{KH} \mathrm{PO}_{4}$ ) were used.

Table S1. Strains, plasmids and primers used in this study

\begin{tabular}{|c|c|c|}
\hline Strains / plasmids /primers & Characteristics & $\begin{array}{l}\text { Source or } \\
\text { reference }\end{array}$ \\
\hline \multicolumn{3}{|l|}{ Strains } \\
\hline E. coli $\mathrm{DH} 5 \alpha$ & Cloning strain, cultured at $37^{\circ} \mathrm{C}$ & Novagen \\
\hline E. coli $\mathrm{BL} 21(\mathrm{DE} 3)$ & Expression strain, cultured at $37^{\circ} \mathrm{C}$ & Novagen \\
\hline \multicolumn{3}{|l|}{ Plasmids } \\
\hline pGEX-4T-3-hmfH & $\begin{array}{l}\text { pGEX-4T-3 containing } h m f H \text { gene from } C \text {. basilensis } \\
\text { HMF14 under the control of Tac promoter, pMB1 } \\
\text { replicon, Amp }{ }^{\mathrm{R}}\end{array}$ & This study \\
\hline pACYCDuet1- $h m f H$ & $\begin{array}{l}\text { pACYCDuet } 1 \text { containing } h m f H \text { gene from } C \text {. basilensis } \\
\text { HMF14 under the control of } 77 \text { promoter at MCS1, P15A } \\
\text { replicon, } \mathrm{Cm}^{\mathrm{R}}\end{array}$ & This study \\
\hline pACYCDuet1-Trc-hmfH & $\begin{array}{l}\text { pACYCDuet1 containing } h m f H \text { gene from C. basilensis } \\
\text { HMF14 under the control of Trc promoter and RBS11 at } \\
\text { MCS1, P15A replicon, } \mathrm{Cm}^{\mathrm{R}}\end{array}$ & This study \\
\hline Primers & Sequence $\left(5^{\prime}-3^{\prime}\right)$ & \\
\hline pGEX-4T-3-hmfH-F & GATCTGGTTCCGCGTGGATCCATGGATACCCCGC & \\
\hline
\end{tabular}


GTGAACGTTTCGATTAC

$\begin{array}{ll}\text { pGEX-4T-3- } h m f H-\mathrm{R} & \text { TCAGTCACGATGCGGCCGCTCGAGTTAGCTCGG } \\ & \text { GTGTGCAACTTCGGAGG } \\ \text { pACYCDuet1- } h m f H-\mathrm{F} & \text { TCATCACCACAGCCAGGATCCGATGGATACCCC } \\ & \text { GCGTGAACGTTTCGATTAC } \\ \text { pACYCDuet1- } h m f H-\mathrm{R} & \text { AAGCATTATGCGGCCGCAAGCTTTTAGCTCGGG } \\ & \text { TGTGCAACTTCGGAGG } \\ \text { pACYCDuet1-Trc- } h m f H-\mathrm{F} & \text { CGACTCCTGCATTAGGAAATTTGACAATTAATCA } \\ & \text { TCCGGCTCG } \\ \text { pACYCDuet1-Trc- } h m f H-\mathrm{R} & \text { TGGTGATGGCTGCTGCCCATAAATTACCGTCCTT } \\ & \text { ATAATCAAATTTTTGTCTGTTCCTGTGTGAAA } \\ & \text { TTGT } \\ \text { pACYCDuet1-T7- } h m f H-\mathrm{F} & \text { ATGGGCAGCAGCCATCACC } \\ \text { pACYCDuet1-T7- } h m f H-\mathrm{R} & \text { ATTTCCTAATGCAGGAGTCGCA }\end{array}$

$A m p^{R}$, Ampicillin resistance. $\mathrm{Cm}^{\mathrm{R}}$, chloramphenicol resistance; $\mathrm{Kan}^{\mathrm{R}}$, kanamycin resistance;

\section{Cloning and heterologous expression of enzymes}

The codon-optimized hmfH gene (GenBank accession number ADE20408.1) from Cupriavidus basilensis HMF14 was synthesized by Sangon Biotech Co., Ltd. (Shanghai, China). To construct the plasmid pACYCDuet1-hmfH, the gene $h m f H$ was cloned into the pACYCDuet1 with T7 promoter using two restriction enzymes $($ Bam $\mathrm{H}$ I and Hind III). The PCR products were ligated with the plasmid pACYCDuet 1 with T7 promoter via in vitro homologous recombination using the Hieff Clone ${ }^{\circledR}$ Plus One Step Cloning Kit (Yeasen Biotech Co., Ltd). To construct the plasmid pACYCDuet1Trc-hmfH, T7 promoter was replaced by Trc and RBS11 was incorporated into the plasmid pACYCDuet1-hmfH by whole-plasmid PCR using the primers containing the mutation sites. The genes encoding SAPDH (GenBank accession number MN460792), CALDH1 (GenBank accession number MN460793), CALDH2 (GenBank accession number MN460794), VDH1 (GenBank accession number MN460795) and VDH2 (GenBank accession number MN460796) from Comamonas testosteroni SC1588 were cloned into pET-28a according to a recent report. ${ }^{1}$ The recombinant plasmids pACYCDuet1-Trc-hmfH and pET-28a-ALDHs were simultaneously transformed into E. coli BL21(DE3), affording engineered whole-cell biocatalysts.

To prepare the whole-cell biocatalyst, the E. coli_VDH1_HmfH cells were typically 
pre-cultivated overnight at $37^{\circ} \mathrm{C}$ and $180 \mathrm{rpm}$ in $5 \mathrm{~mL} \mathrm{LB}$ medium supplemented with $17 \mathrm{mg} / \mathrm{L}$ of chloramphenicol and $25 \mathrm{mg} / \mathrm{L}$ of kanamycin. Then, $1 \mathrm{~mL}$ of an overnight culture was inoculated into $100 \mathrm{~mL} \mathrm{~TB}$ medium containing $17 \mathrm{mg} / \mathrm{L}$ of chloramphenicol and $25 \mathrm{mg} / \mathrm{L}$ of kanamycin and incubated at $37{ }^{\circ} \mathrm{C}$ and $180 \mathrm{rpm}$. When the optical density of the culture at $600 \mathrm{~nm}$ reached 0.8 , isopropyl $\beta$-D-thiogalactoside (IPTG) was added to the medium (the final concentration of $0.2 \mathrm{mM}$ ) to induce the enzyme expression. After the cultivation was performed at $20^{\circ} \mathrm{C}$ and $160 \mathrm{rpm}$ for $20 \mathrm{~h}$, the cells were collected by centrifugation ( $8000 \mathrm{rpm}, 3 \mathrm{~min}, 4{ }^{\circ} \mathrm{C}$ ) and washed twice with $0.85 \%$ $\mathrm{NaCl}$ solution, then resuspended in phosphate buffer $(0.2 \mathrm{M}, \mathrm{pH} 7.0)$ to a final cell concentration of $150 \mathrm{mg} / \mathrm{mL}$ (wet weight).

Whole-cell catalytic oxidation of HMF. Typically, $4 \mathrm{~mL}$ of phosphate buffer $(0.2 \mathrm{M}$, $\mathrm{pH}$ 7.0) containing $50 \mathrm{mM}$ HMF and $50 \mathrm{mg} / \mathrm{mL}$ (cell wet weight) microbial cells was incubated at $30^{\circ} \mathrm{C}$ and $150 \mathrm{rpm}$. Aliquots were withdrawn from the reaction mixtures at specified time intervals and diluted with the corresponding mobile phase prior to HPLC analysis. The initial reaction rate was defined as the decrease in the reduced HMF amounts per min within initial $10 \mathrm{~min}$. The conversion was defined as the percentage of the consumed HMF amount in the initial HMF amount. The yield was defined as the percentage of the measured product amount in the theoretical product amount based on the initial amount of HMF. All the experiments were conducted at least in duplicate, and the values were expressed as the means \pm standard deviations.

HPLC analysis. The reaction mixtures were analyzed on a Zorbax Eclipse XDB-C18 column $(4.6 \mathrm{~mm} \times 250 \mathrm{~mm}, 5 \mu \mathrm{m}$, Agilent, USA) by using a reversed phase HPLC equipped with a Waters 996 photodiode array detector (Waters, USA). For the analysis of the reaction mixtures, the mobile phase was a mixture of acetonitrile/ $0.4 \%$ $\left(\mathrm{NH}_{4}\right)_{2} \mathrm{SO}_{4}$ solution with $\mathrm{pH} 3.5(10: 90, \mathrm{v} / \mathrm{v})$ at a flow rate of $0.6 \mathrm{~mL} / \mathrm{min}$. The retention times of FDCA (maximum absorption wavelength: $264 \mathrm{~nm})$, FFCA (286 nm), HMFCA (252 nm), BHMF (223 nm), HMF (283 nm) and DFF (288 nm) were 4.8, 6.0, 6.1, 8.1, 
9.7 and $12.6 \mathrm{~min}$, respectively.

Cell viability assay. Cell viability was measured by PI staining and flow cytometry. ${ }^{2}$ Briefly, the cells were harvested after incubation for $12 \mathrm{~h}$ under the designated conditions and diluted to $10^{6}$ colony-forming units per $\mathrm{mL}$ with $0.85 \% \mathrm{NaCl}$ solution. The cells were stained with $10 \mu \mathrm{g} / \mathrm{mL}$ PI (avoid light) for $15 \mathrm{~min}$, and the cell viability was assayed using a Gallios flow cytometer (Beckman Coulter Inc., USA), which use ECD channel (610/20BP) with excitation wavelength of $488 \mathrm{~nm}$. All the experiments were conducted at least in duplicate, and the values were expressed as the means \pm standard deviations.

Scale-up synthesis and isolation of FDCA. Fifty milliliters of phosphate buffer $(0.2$ $\mathrm{M}, \mathrm{pH}$ 7.0) containing approximately $52 \mathrm{mM} \mathrm{HMF}$ and $150 \mathrm{mg} / \mathrm{mL}$ (cell wet weight) microbial cells was incubated at $30{ }^{\circ} \mathrm{C}$ and $150 \mathrm{rpm}$. After $1 \mathrm{~h}, \mathrm{HMF}$ of approximately $44 \mathrm{mM}$ was supplemented. $\mathrm{pH}$ of the reaction mixture was adjusted to approximately 7.0 by adding $\mathrm{NaHCO}_{3}$ after $2 \mathrm{~h}$, followed by $\mathrm{pH}$ tuning to 7.0 every $12 \mathrm{~h}$. The changes in the concentrations of various chemicals were monitored by HPLC. After $36 \mathrm{~h}$, the cells were removed by centrifugation (10000 rpm, $20 \mathrm{~min}$ ). The supernatant was boiled for $10 \mathrm{~min}$, followed by centrifugation (10000 rpm, $20 \mathrm{~min}$ ). The obtained supernatant was acidified to $\mathrm{pH} 0.5$ by adding $50 \%$ (w/v) $\mathrm{H}_{2} \mathrm{SO}_{4}$, thus precipitating FDCA. Upon centrifugation, the precipitate was washed 3 times with $5 \%(\mathrm{w} / \mathrm{v}) \mathrm{H}_{2} \mathrm{SO}_{4}$, while the supernatant was saturated with excess $\mathrm{NaCl}$, followed by extraction 3 times with the same volume of tetrahydrofuran (THF). The above precipitate was re-solubilized in $\mathrm{NaOH}$ solution, and acidified to $\mathrm{pH} 0.5$ by adding $50 \%$ (w/v) $\mathrm{H}_{2} \mathrm{SO}_{4}$. Then, excess $\mathrm{NaCl}$ was added into the mixture, followed by extraction 3 times with the same volume of THF. All the organic phases were combined, and anti-extracted 3 times by saturated $\mathrm{NaCl}$ solution to remove water. The organic phase was dried over anhydrous $\mathrm{Na}_{2} \mathrm{SO}_{4}$ overnight. The product was obtained upon solvent evaporation. 


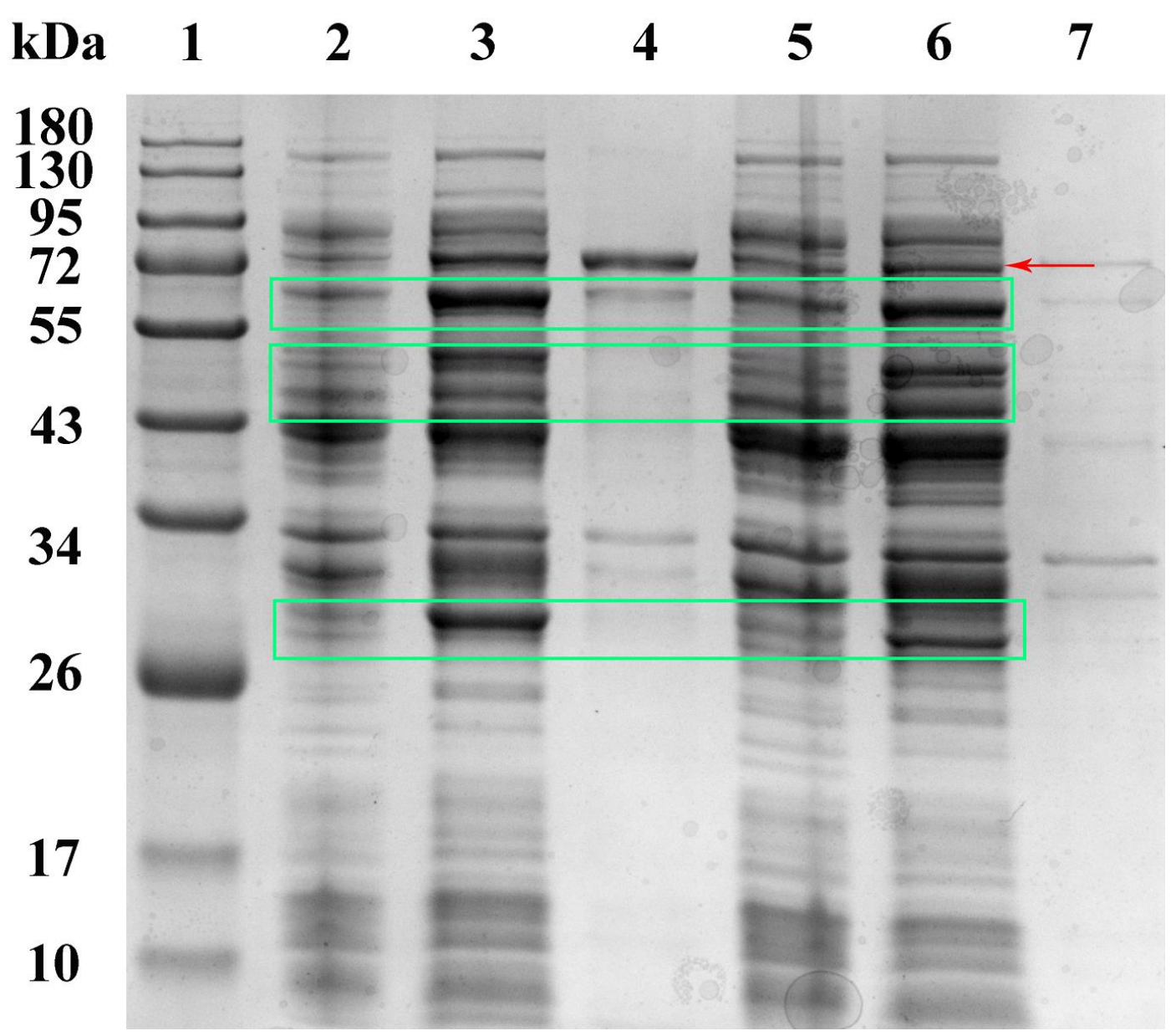

Figure S1. SDS-PAGE analysis of the recombinant proteins present in the cells harboring pGEX-4T-3-hmfH. Lane 1: protein marker; lanes 2 and 5: the supernatant of the cells harboring empty vector (the control) induced by $0.1 \mathrm{mM}$ IPTG; lane 3: the supernatant of the cells harboring pGEX-4T-3-hmfH induced by $0.1 \mathrm{mM} \mathrm{IPTG}$; lane 4: the precipitant of the cells harboring pGEX-4T-3-hmfH; lane 6: the supernatant of the cells harboring pGEX-4T-3-hmfH induced by both $0.1 \mathrm{mM}$ IPTG and 3\% ethanol; lane 7: the precipitant of the cells harboring pGEX-4T-3-hmfH induced by both $0.1 \mathrm{mM}$ IPTG and 3\% ethanol. The theoretical molecular weight of the desired protein is approximately $62.3 \mathrm{kDa}$. The molecular weight of the recombinant protein increases to $88 \mathrm{kDa}$ due to the presence of GST-tag. The desired protein was pointed at by the red arrow. Changes in the protein expression in the cells upon the incorporation of $\mathrm{HmfH}$ were indicated in green rectangles.

Cultivation conditions: The recombinant plasmids were transformed into E. coli BL21(DE3) and pre-cultivated overnight in $5 \mathrm{~mL} \mathrm{LB}$ medium containing $100 \mathrm{mg} / \mathrm{L}$ 
ampicillin at $37^{\circ} \mathrm{C}$ and $180 \mathrm{rpm}$. Then, $100 \mathrm{~mL}$ LB medium containing $100 \mathrm{mg} / \mathrm{L}$ ampicillin was inoculated with $1 \mathrm{~mL}$ of an overnight culture. Cells were grown at $37^{\circ} \mathrm{C}$ and $180 \mathrm{rpm}$. When the optical density at $600 \mathrm{~nm}$ (OD600) reached 0.6-0.8, the inducer (0.1 mM IPTG and 3\% ethanol) was added for inducing protein expression, followed by incubation at $20^{\circ} \mathrm{C}$ for $20 \mathrm{~h}$ and $160 \mathrm{rpm}$.

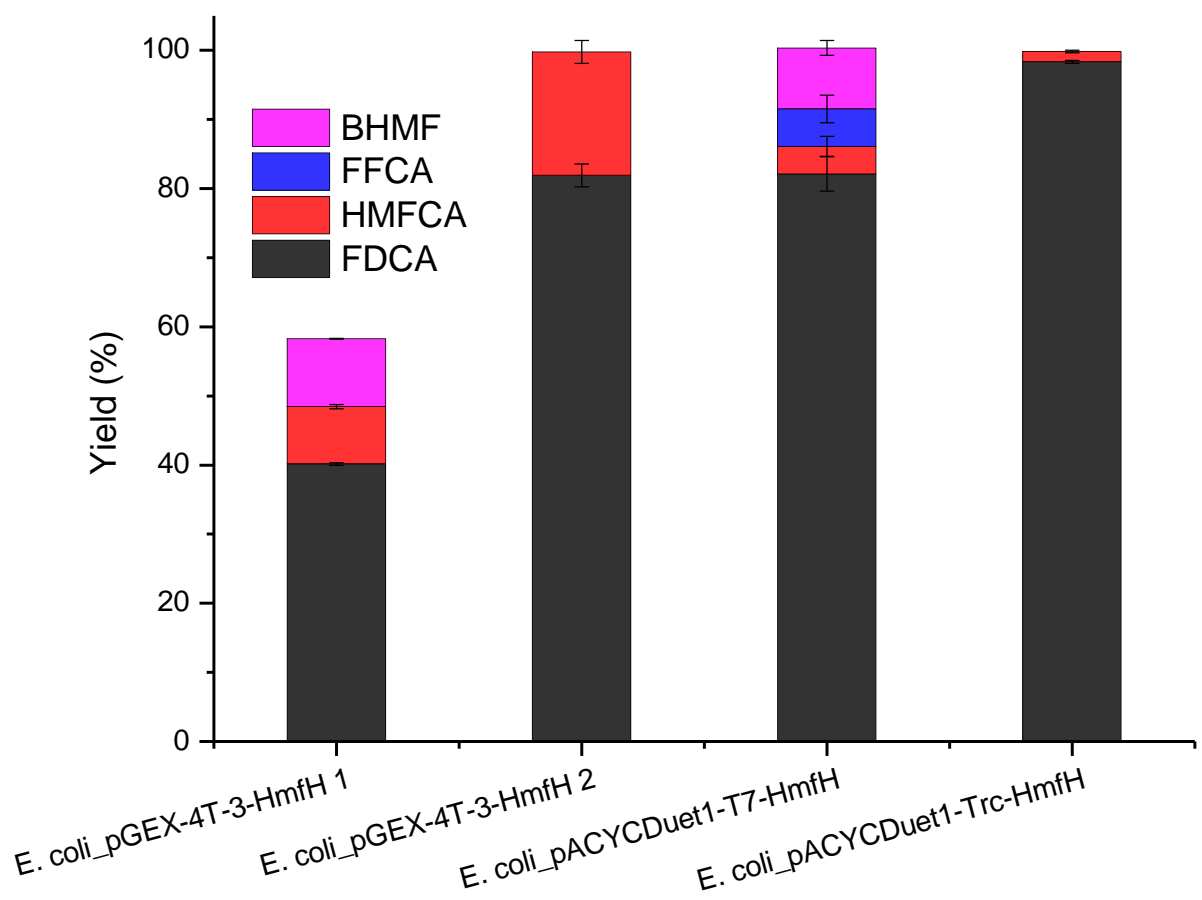

Figure S2. Comparison of the catalytic activities of the recombinant strains. Reaction conditions: $50 \mathrm{mM} \mathrm{HMF}, 50 \mathrm{mg} / \mathrm{mL}$ (wet weight) microbial cells, $4 \mathrm{~mL}$ phosphate buffer $(0.2 \mathrm{M}, \mathrm{pH} 7.0), 150 \mathrm{rpm}, 30{ }^{\circ} \mathrm{C}, 96$ h. E. coli_pGEX-4T-3-HmfH 1: the cells induced by $0.1 \mathrm{mM}$ IPTG; E. coli_pGEX-4T-3-HmfH 2: the cells induced by both 0.1 mM IPTG and 3\% ethanol. 
(a)

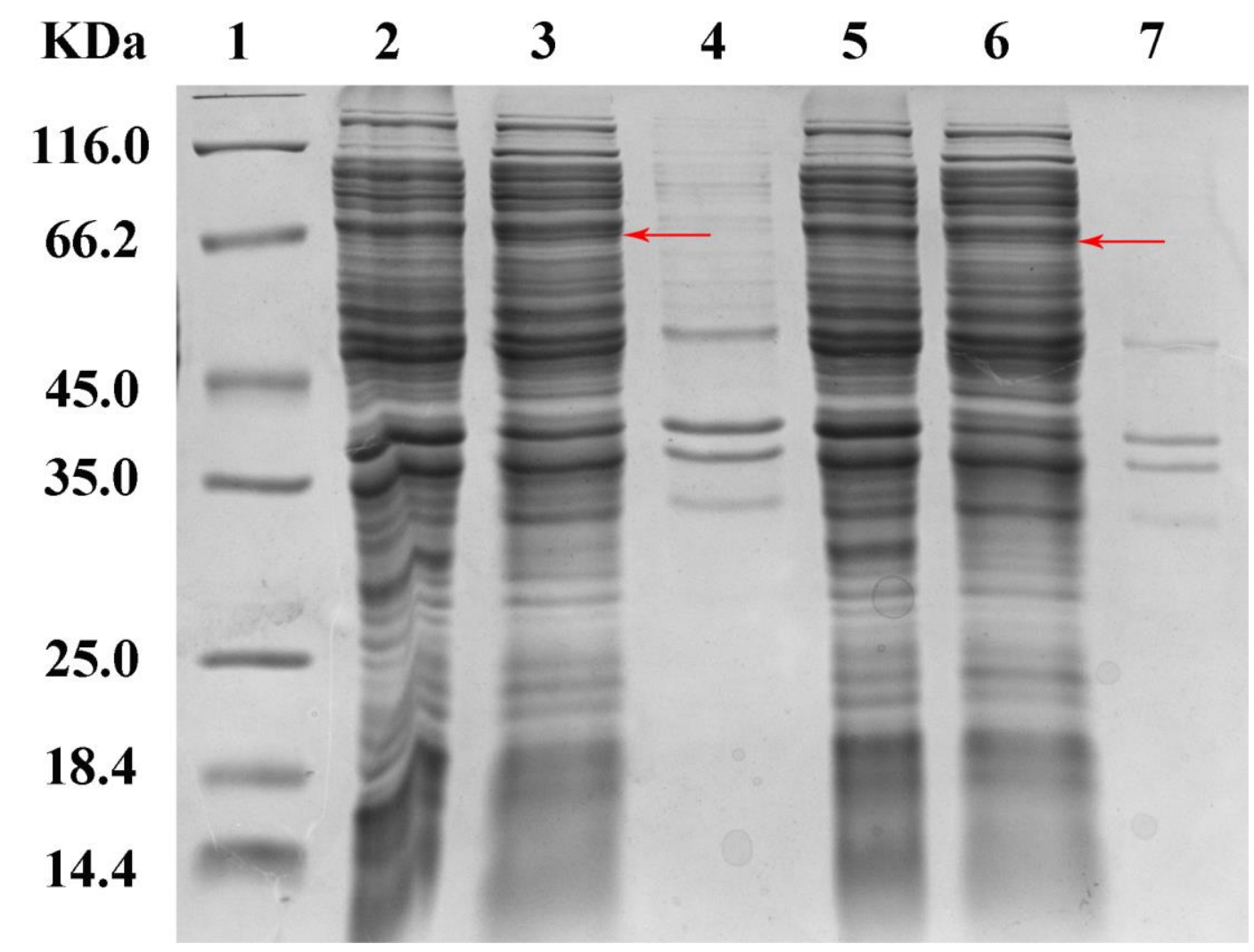

(b)

$\begin{array}{llll}\text { kDa } & 1 & 2 & 3\end{array}$

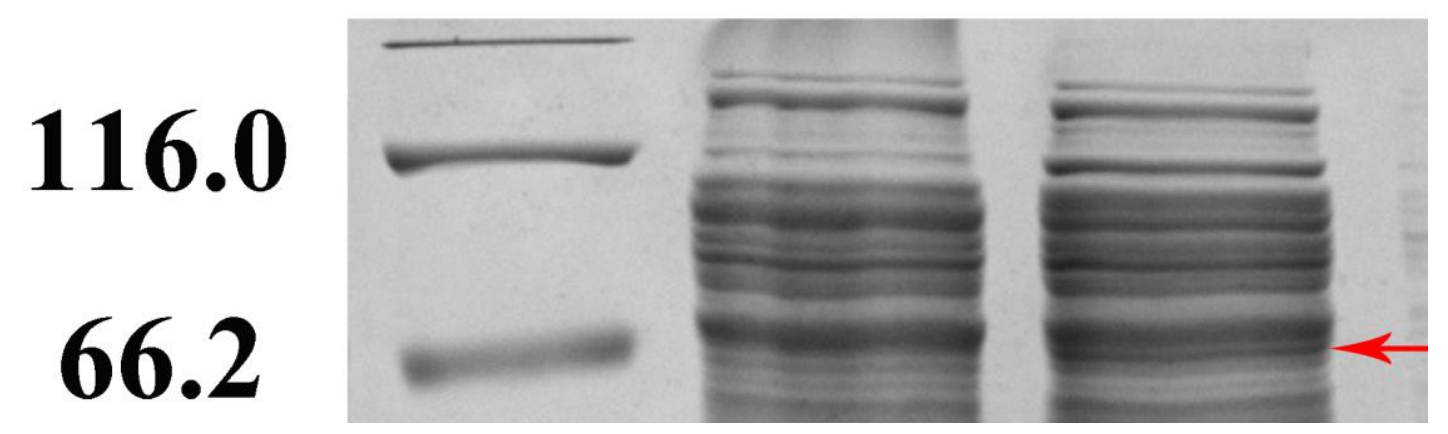




\section{(c)}
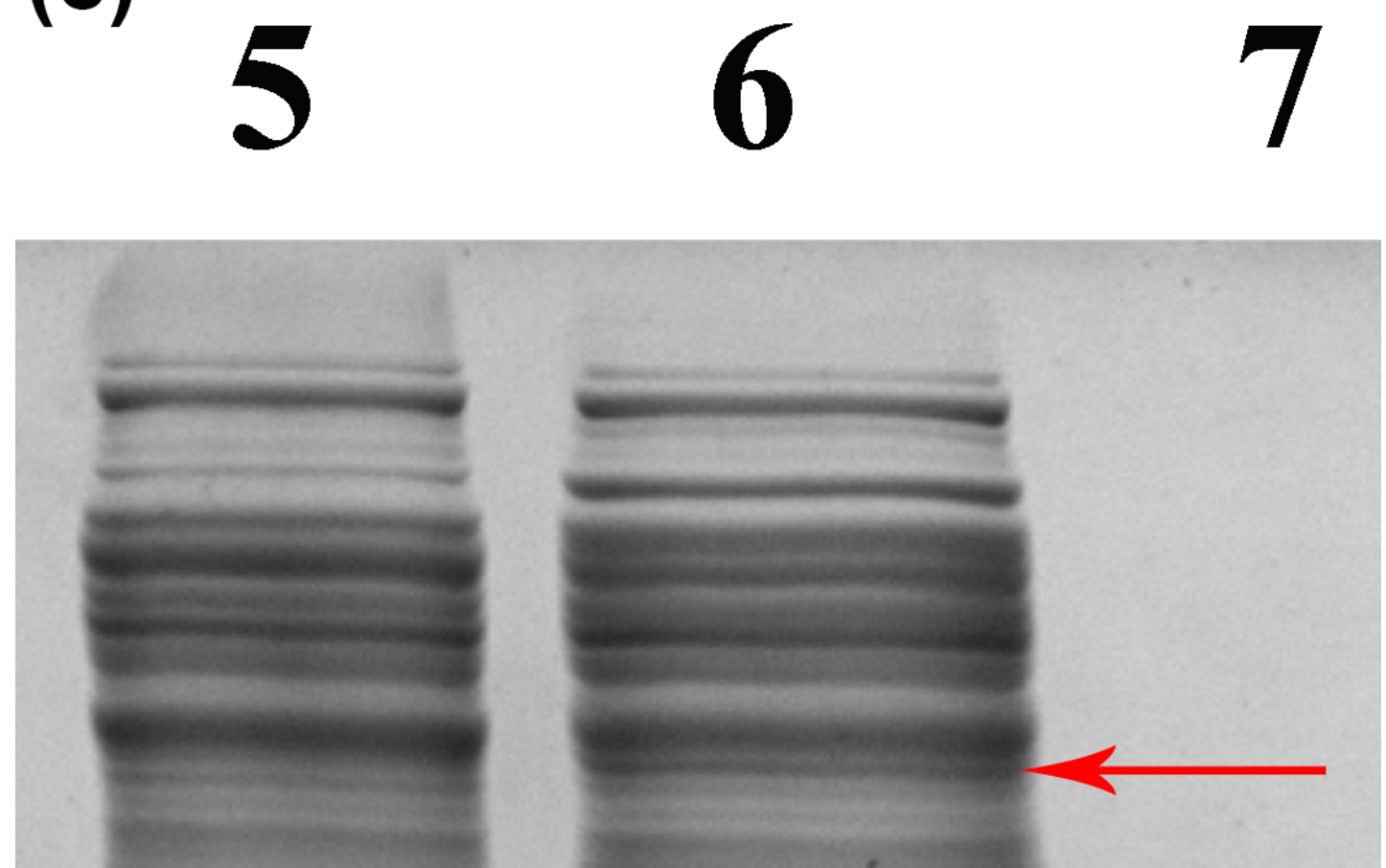

Figure S3. SDS-PAGE analysis of the recombinant proteins present in the cells harboring pACYCDuet1-hmfH (a), magnification of lanes 1-3 (b), magnification of lanes 5-7 (c). Lane 1: protein marker; lanes 2 and 5: the supernatant of the cells harboring empty vector (the control); lane 3: the supernatant of the cells harboring pACYCDuet1-Trc-hmfH; lane 4: the precipitant of the cells harboring pACYCDuet1Trc-hmfH; lane 6: the supernatant of the cells harboring pACYCDuet1-hmfH; lane 7: the precipitant of the cells harboring pACYCDuet1-hmfH. The desired protein was pointed at by the red arrow. As shown in Figure S3b and c, a new, yet weak band appeared. Changes in the protein expression in the cells upon the incorporation of $\mathrm{HmfH}$ were indicated in green rectangles. 

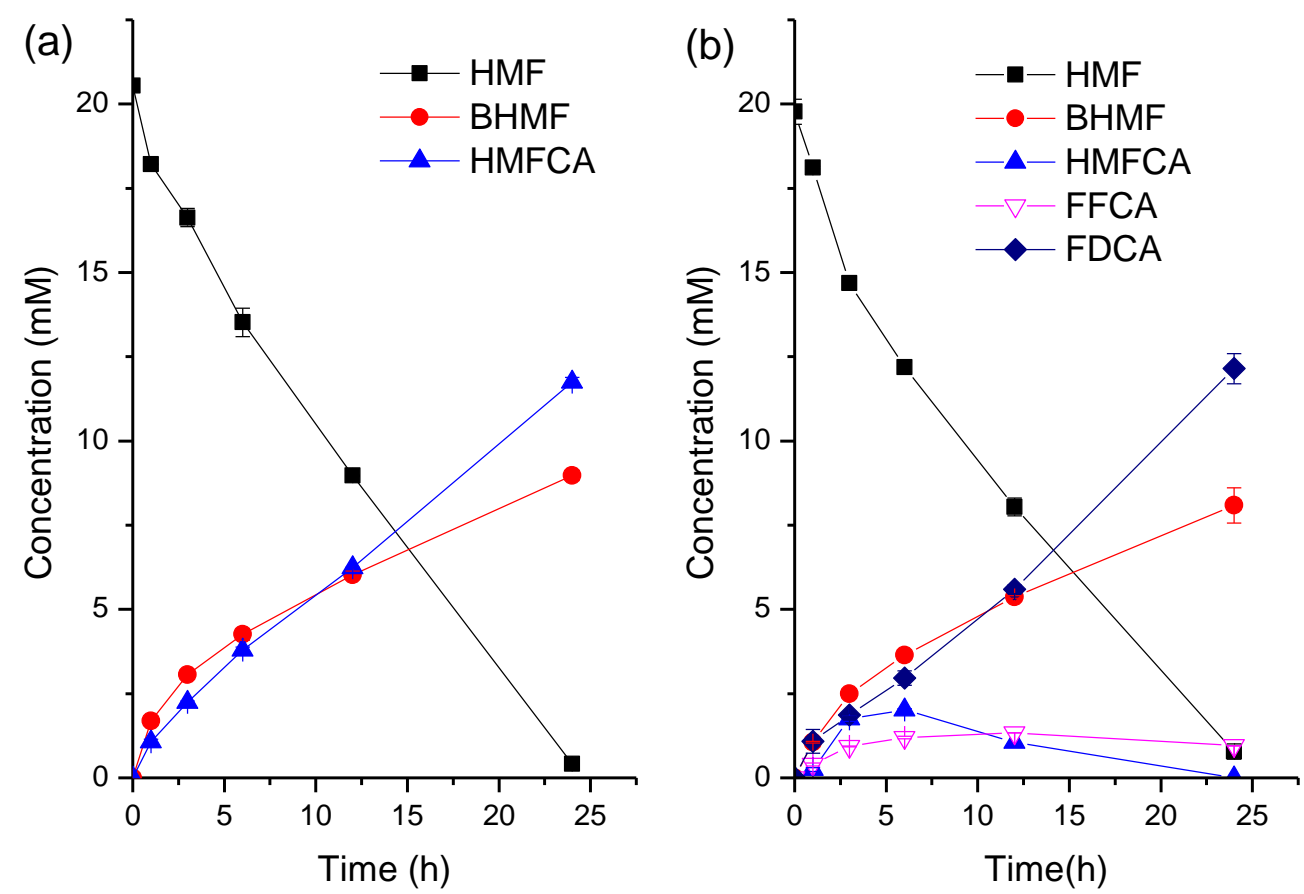

Figure S4. Biotransformation of HMF by recombinant cells cultivated in LB medium: (a) harboring empty vector; (b) harboring pACYCDuet1-Trc-hmfH. Reaction conditions: $20 \mathrm{mM} \mathrm{HMF}, 50 \mathrm{mg} / \mathrm{mL}$ (wet weight) microbial cells, $4 \mathrm{~mL}$ phosphate buffer (0.2 M, pH 7.0), $150 \mathrm{rpm}, 30^{\circ} \mathrm{C}$

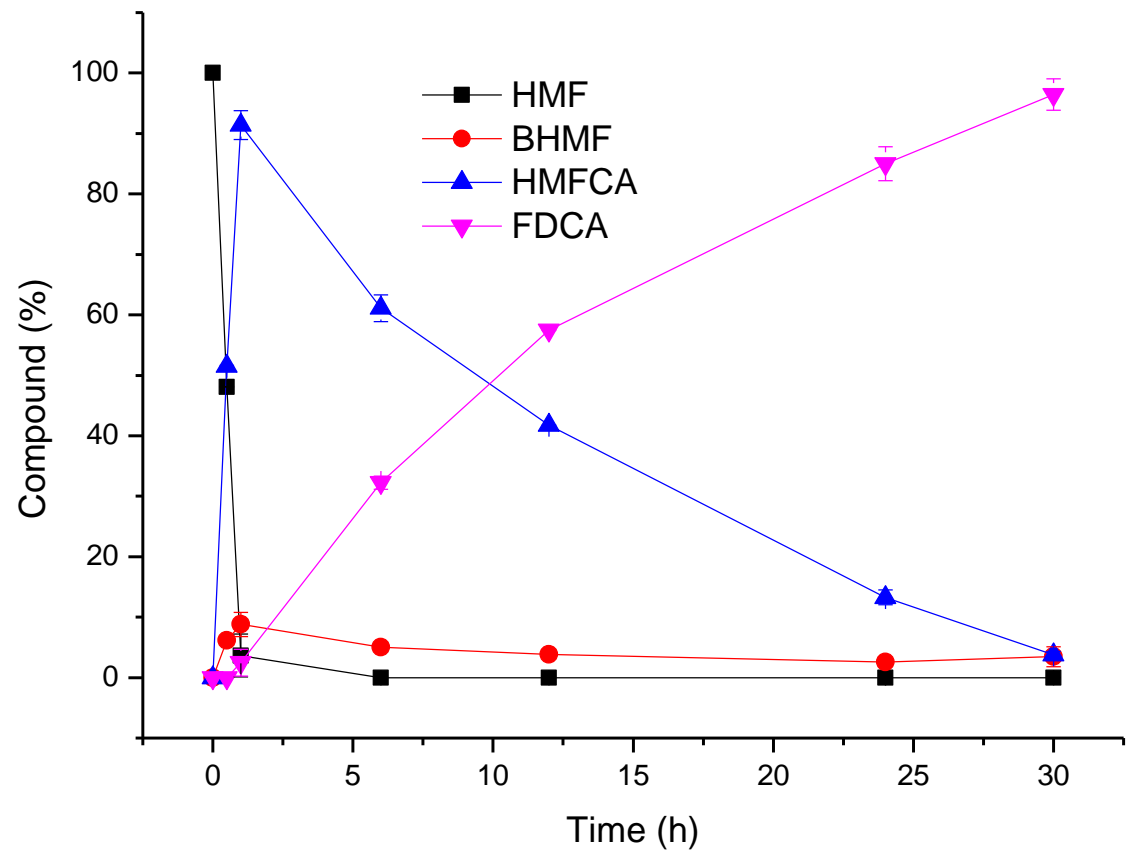

Figure S5. Time courses of HMF oxidation catalyzed by E. coli_VDH1_HmfH. 
Reaction conditions were the same as those in Figure 1.

Table S2. Effect of $\mathrm{pH}$ on biocatalytic oxidation of HMF

\begin{tabular}{lllllll}
\hline Buffers & Initial pH & $\begin{array}{l}\text { FDCA } \\
\text { yield (\%) }\end{array}$ & $\begin{array}{l}\text { HMFCA } \\
\text { yield (\%) }\end{array}$ & $\begin{array}{l}\text { BHMF } \\
\text { yield (\%) }\end{array}$ & $\begin{array}{l}\text { HMF } \\
\text { Conv. (\%) }\end{array}$ & $\begin{array}{l}\text { pH upon } \\
\text { reaction }\end{array}$ \\
\hline $\mathrm{Na}_{2} \mathrm{HPO}_{4}$-citric & 5 & 0 & $49 \pm 1$ & $3 \pm 0$ & $51 \pm 1$ & 4.4 \\
acid buffer & 6 & $6 \pm 2$ & $92 \pm 0$ & $8 \pm 0$ & $>99$ & 5.6 \\
Phosphate buffer & 6 & $2 \pm 0$ & $83 \pm 1$ & $10 \pm 3$ & $91 \pm 3$ & 4.7 \\
& $\mathbf{7}$ & $\mathbf{9 4} \pm \mathbf{1}$ & $\mathbf{5} \pm \mathbf{1}$ & $\mathbf{2} \pm \mathbf{0}$ & $>\mathbf{9 9}$ & $\mathbf{6 . 2}$ \\
& 8 & $65 \pm 1$ & $38 \pm 1$ & $1 \pm 0$ & $>99$ & 6.8 \\
HEPES buffer & 7 & $69 \pm 4$ & $32 \pm 3$ & $8 \pm 1$ & $>99$ & 5.1 \\
& 8 & $70 \pm 1$ & $31 \pm 1$ & $9 \pm 1$ & $>99$ & 5.2 \\
Glycine-NaOH & 9 & $2 \pm 0$ & $60 \pm 1$ & $4 \pm 1$ & $67 \pm 1$ & 4.6 \\
buffer & & & & & & \\
\hline
\end{tabular}

Reaction conditions: $50 \mathrm{mM} \mathrm{HMF,} 50 \mathrm{mg} / \mathrm{mL}$ (wet weight) microbial cells, $2 \mathrm{~mL}$ buffer (0.2 M, pH 5-9), $150 \mathrm{rpm}, 30^{\circ} \mathrm{C}, 30 \mathrm{~h}$

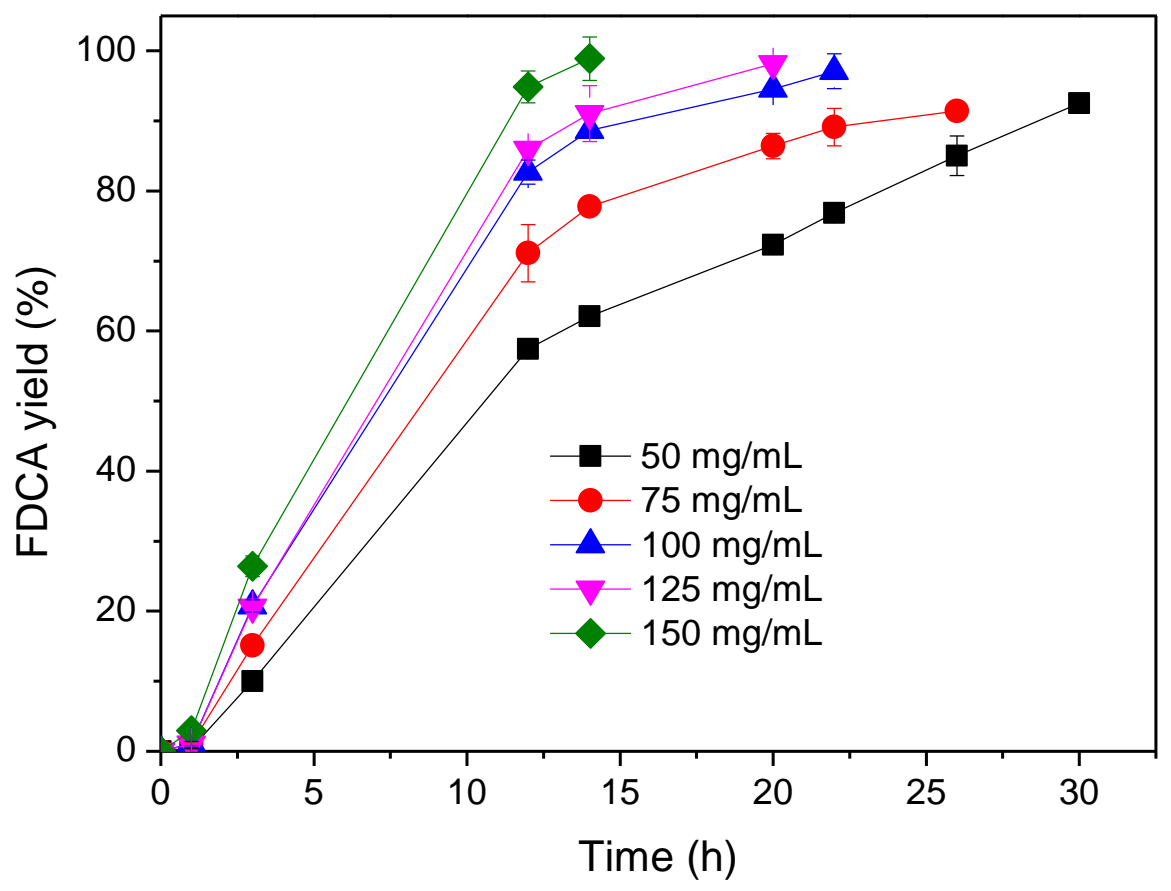

Figure S6. Effect of the cell concentrations on the FDCA synthesis. Reaction conditions: $50 \mathrm{mM} \mathrm{HMF}$, the designated concentration (wet weight) of microbial cells, $4 \mathrm{~mL}$ phosphate buffer $(0.2 \mathrm{M}, \mathrm{pH} 7.0), 150 \mathrm{rpm}, 30^{\circ} \mathrm{C}$. 

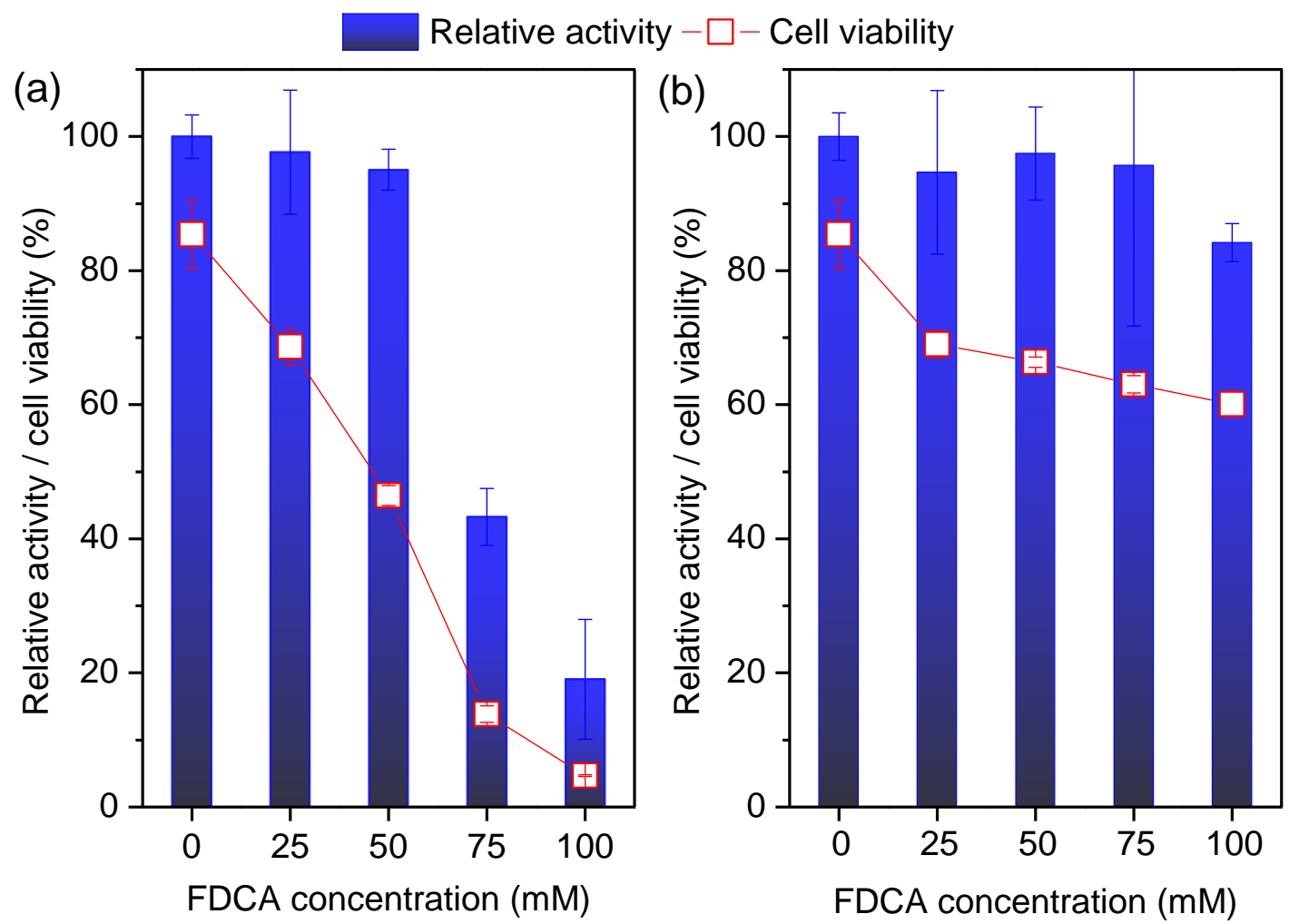

Figure S7. Effect of the product concentrations on the catalytic activity and viability of the cells: (a) without $\mathrm{pH}$ tuning; (b) after $\mathrm{pH}$ tuning. Reaction conditions for (a): 50 $\mathrm{mM}$ HMF, the designated concentration of FDCA, $150 \mathrm{mg} / \mathrm{mL}$ (wet weight) microbial cells, $4 \mathrm{~mL}$ phosphate buffer $\left(0.2 \mathrm{M}\right.$, pH 7.0), $150 \mathrm{rpm}, 30{ }^{\circ} \mathrm{C}$; after $150 \mathrm{mg} / \mathrm{mL}$ of microbial cells were incubated for $12 \mathrm{~h}$ in phosphate buffer $(0.2 \mathrm{M}, \mathrm{pH} 7.0)$ containing the designated concentration of FDCA at $150 \mathrm{rpm}$ and $30{ }^{\circ} \mathrm{C}$, cell viability was measured. Reaction conditions for (b) were similar to the above ones, with the exception that the $\mathrm{pH}$ of the reaction mixture was tuned to 7.0 by adding $\mathrm{NaOH}$ prior to reaction/incubation. 


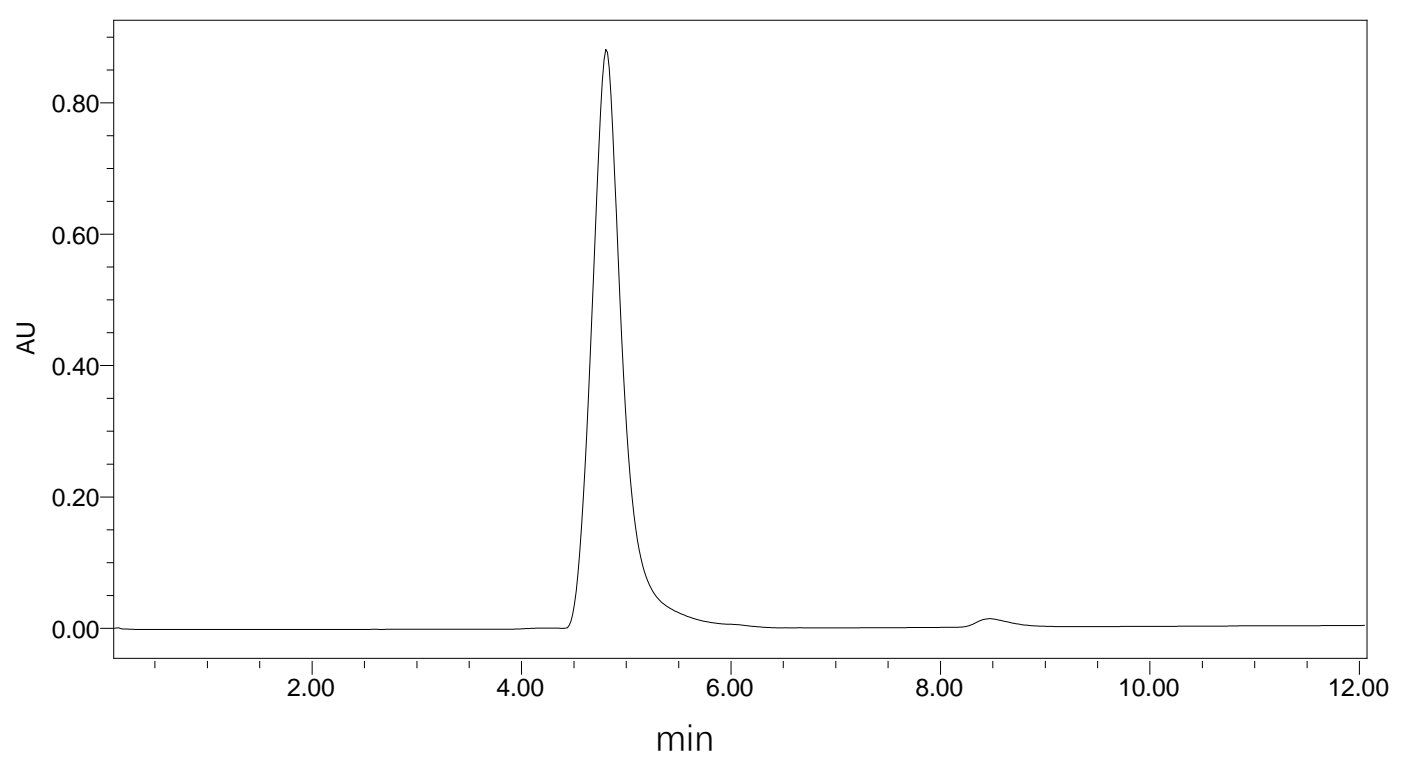

Figure S8. HPLC spectrum of FDCA isolated

Table S3. Estimation of the waste generated in gram-scale preparation of FDCA

\begin{tabular}{cr}
\hline Component & E factor contribution (kg waste per kg product) \\
\hline water & 571.4 \\
buffer salt & 1.9 \\
cells & 2.7 \\
$\mathrm{Na}_{2} \mathrm{SO}_{4}$ & 9.0 \\
$\mathrm{NaCl}$ & 180.0 \\
$\mathrm{THF}$ & 381.4 \\
$\mathrm{Sum}$ & 1146.4 \\
\hline
\end{tabular}

\section{References}

(1) Zhang, X.-Y.; Ou, X.-Y.; Fu, Y.-J.; Zong, M.-H.; Li, N., Efficient Synthesis of 5Hydroxymethyl-2-Furancarboxylic Acid by Escherichia Coli Overexpressing Aldehyde Dehydrogenases. J. Biotechnol. 2020, 307, 125-130. 10.1016/j.jbiotec.2019.11.007

(2) Shi, S.-S.; Zhang, X.-Y.; Zong, M.-H.; Wang, C.-F.; Li, N., Selective Synthesis of 2-Furoic Acid and 5-Hydroxymethyl-2-Furancarboxylic Acid from Bio-Based Furans by Recombinant Escherichia Coli Cells. Mol. Catal. 2019, 469, 68-74. 10.1016/j.mcat.2019.03.006 